\author{
T. Гуржій, \\ доктор юридичних наук, професор, \\ завідувач кафедри адміністративного, фінансового та інформаційного права \\ Київського національного торговельно-економічного університету
}

\title{
ПРАВОВЕ ЗАБЕЗПЕЧЕННЯ ЕЛЕКТРОННОЇ ФОРМИ ДЕКЛАРУВАННЯ ПІД ЧАС МИТНОГО ОФОРМЛЕННЯ
}

У сучасному глобальному світі концепція державного управління, яка отримала назву «електронний уряд», надійно посіла своє місце в архітектурі державного управління та публічного адміністрування. Ця концепція заснована на використанні інформаційних та телекомунікаційних технологій, метою iï запровадження $є$ підвищення ефективності та прозорості влади, а також установлення системи надійного суспільного контролю над нею. Концепція є одним із фундаментальних складників загальної системи електронного урядування.

Інформаційні технології продовжують охоплювати все нові сфери підприємницької діяльності, електронним стає і митне оформлення товарів. Роль інформаційних технологій у митній справі сформульовано в Міжнародній конвенції про спрощення та гармонізацію митних процедур (Кіотська конвенція 1999 р.), яка передбачає максимальне практичне використання інформаційних технологій як одного з принципів митного оформлення, реалізація якого повинна сприяти спрощенню i гармонізації митних процедур, а також установлює стандартне правило використання інформаційних технологій і засобів електронних комунікацій для вдосконалення митного контролю [1].

Питання електронного декларування як складової частини концепції «електронна митниця» давно стало предметом вивчення вітчизняних фахівців у галузі адміністративного і митного права. Зокрема, увагу досліджуваному питанню приділили Ю.П. Битяк, I.Г. Бережнюк, К.Г. Борисов, І.В. Бойко, А.Д. Войцещук, Є.В. Додін, А.Т. Комзюк, Ю.Д. Кунєв, П.В. Пашко, Д.В. Приймаченко, В.В. Прокопенко та ін.

Створення сучасної інформаційної інфраструктури митних органів $€$ головним завданням загальнодержавного масштабу, реалізувати його можливо тільки за допомогою системного підходу, який гарантує ефективне інформаційно-правове забезпечення всіх напрямів ії діяльності на основі накопиченого теоретичного і практичного досвіду митних органів та учасників зовнішньоекономічної діяльності.

Мета статті полягає у визначенні організаційних і правових засад здійснення інформаційного забезпечення діяльності митних органів та розробленні рекомендацій щодо вдосконалення електронного митного декларування товарів та транспортних засобів комерційного призначення як складової частини процесу митного оформлення.

Правову основу інформаційного забезпечення діяльності митних органів України становлять Конституція України [2], Кіотська конвенція про спрощення та гармонізацію митних процедур, Митний кодекс України [3], 
Закон України «Про інформацію» [4] та інші нормативно-правові акти.

Положення зазначених концептуальних нормативних джерел знайшли свій розвиток у нормативних документах Державної митної служби України, нормативних документах, що регламентують діяльність інших підприємств і організацій, які беруть участь у технологічному процесі переміщення товарів і транспортних засобів комерційного призначення через митний кордон України, технологіях митного контролю та митного оформлення, інструкціях і положеннях, затверджених на рівні митниць, а також положеннях, що нормативно закріплюють та деталізують перелік функцій окремих структурних підрозділів митних органів України.

Особливе місце інформаційних технологій у митній справі відображено в Міжнародній конвенції про спрощення та гармонізацію митних процедур (Кіотській конвенціі), яка передбачає максимальне практичне використання інформаційних технологій і розглядає інформаційні технології як один із принципів митного оформлення, реалізація якого має сприяти гармонізації і спрощенню митних процедур. Правові норми, які закріплені в Конвенції, встановлюють стандартні правила використання інформаційних технологій і засобів електронних комунікацій із метою вдосконалення митного контролю [1].

Так, у главі 7 («Застосування інформаційних технологій») Загальних положень визначено, що митні служби використовують інформаційні технології для успішного здійснення митних операцій у випадках, коли це виявляється економічно ефективним як для неї, так і для торгового співтовариства.

У процесі дослідження проблематики електронного декларування під час митного оформлення необхідно звернути увагу на правові норми, що закріплені в Митному кодексі України і визначають поняття митного декларування через його форму. А саме норми, закріплені у ст. 257 Митного кодексу
України, встановлюють, що декларування здійснюється шляхом заявлення за встановленою формою (письмовою, усною, шляхом учинення дій) точних відомостей про товари, мету їх переміщення через митний кордон України, а також відомостей, необхідних для здійснення їх митного контролю та митного оформлення. Під час застосування письмової форми декларування можуть використовуватися як електронні документи, так і документи на паперовому носії або їхні електронні (скановані) копії, засвідчені електронним цифровим підписом декларанта або уповноваженої ним особи.

Електронне декларування здійснюється 3 використанням електронної митної декларації, засвідченої електронним цифровим підписом, та інших електронних документів або їхніх реквізитів у встановлених законом випадках, а також електронних (сканованих) копій паперових документів, засвідчених електронним цифровим підписом декларанта або уповноваженої ним особи [3].

Необхідно зауважити, що правові засади застосування електронного цифрового підпису в електронних документах закріплені в Законі України «Про електронні довірчі послуги» [5] і технологічно реалізуються шляхом надання електронних довірчих послуг відповідно до зазначеного Закону.

Досліджуючи правові засади електронного декларування під час митного оформлення, необхідно зауважити, що розроблення сучасної технологічної структури «електронної митниці», яка забезпечує процеси централізованого моніторингу й управління центральною та резервною базами даних ДМСУ, технічними структурами зв'язку, серверами, робочими станціями, якими обладнані АРМи (автоматизовані робочі місця) посадових осіб митних органів, іншим телекомунікаційним обладнанням, а також системами, які дають змогу здійснювати управління технічними засобами митного контролю, було започатковано Розпоряджен- 
ням Кабінету Міністрів України від 17.09.08 № 1236-р., яким була схвалена Концепція створення багатофункціональної комплексної системи «Електронна митниця» [6].

Вітчизняна дослідниця в галузі митної справи А.О. Крижанівська зазначає, що найбільш суттєвим кроком щодо впровадження концепції е-Митниці було затвердження Багаторічного стратегічного плану для «Електронної митниці» [7].

Аналізуючи положення цього документа, безумовно, погоджуємося з думкою автора.

Варто зазначити, що електронне декларування під час митного оформлення $€$ лише складовою частиною розвинутої системи інформаційного забезпечення ДМС України. Сьогодні весь загал структурних підрозділів митної служби так чи інакше здійснює обробку інформації. До речі, діяльність митної служби можна визначати як діяльність, що пов'язана з отриманням, обробкою, використанням та збереженням інформації.

Досліджуючи питання інформаційного забезпечення та функціонування органів державної влади, А.I. Таіров визначає виокремлені складники інформаційного забезпечення діяльності митних органів України, як: інформаційну підтримку - надання конфіденційної інформації керівництву та іншим правоохоронним органам, необхідної для виконання поставлених завдань; інформаційне супроводження - проведення комплексу інформаційно-пропагандистських або ідеологічних заходів; інформаційне обслуговування - діяльність спеціальних служб із виявлення й задоволення актуальних інформаційних потреб митних органів; інформаційну допомогу - надання своєчасної й кваліфікованої допомоги суб'єктам митної сфери у доступі до необхідних інформаційних ресурсів і засобів у зв'язку 3 виконанням складних завдань або виникненням нових проблем у здійсненні митної політики; інформаційну логістику - управління інформаційними потоками у процеcax забезпечення митної діяльності матеріально-технічними засобами, товарами, фінансовими, інформаційними та іншими послугами з метою їх оптимізаціі; інформаційне консультування - надання спеціальними органами й службами силовим відомствам консалтингових послуг, експертних оцінок, розроблення рекомендацій і пропозицій для вирішення проблем, що виникають у процесі інформаційно-комунікаційної взаємодії суб'єктів і об'єктів політики держави [7].

Із деякими аспектами дослідження, що його пропонує до уваги автор, важко погодитися, адже 3 огляду на суто імперативний і владно управлінський характер діяльності Державної митної служби України як спеціально уповноваженого центрального органу виконавчої влади в галузі митної справи дещо важко віднести до характерних завдань митних органів «проведення комплексу інформаційно-пропагандистських або ідеологічних заходів». Водночас цілком слушним є тезис щодо представлення діяльності органів митного контролю як діяльності, що пов'язана з обробкою певних масивів інформації.

У Державній митній службі України з 1992 р. створено та успішно функціонує Єдина автоматизована інформаційна система (ЄAIC), яка об'єднує у собі всі програмно-технічні складники, необхідні для автоматизації процесів митного оформлення та контролю. Діюча в іiі складі автоматизована система митного оформлення «Інспектор» (ACMO) охоплює всі процеси митного контролю як усередині країни, так і на митних кордонах.

До складу ЄAIC митних органів зараховують такі елементи:

автоматизовану інформаційну систему «Центр» - це автоматизована інформаційна система центрального рівня, яка становить сукупність підсистем, комплексів завдань, програмно-інформаційних комплексів та централізованого сховища зведеної інформації про митне оформлення - електронних 
копій вантажних митних декларацій на паперовому носії та електронних вантажних митних декларацій, інших електронних документів та електронних копій документів на паперовому носії, які використовуються під час здійснення митного контролю та оформлення товарів і транспортних засобів, що переміщаються через митний кордон України, та забезпечує двосторонній обмін митною та іншою інформацією з автоматизованими системами митного оформлення та іншими системами (підсистемами) локального рівня;

автоматизовану систему митного оформлення (ACMO) - це підсистема, що входить до складу Єдиної автоматизованої інформаційної системи митних органів і забезпечує використання електронних документів та електронних копій документів на паперових носіях посадовими особами митного органу для здійснення митних процедур, а також локальні підсистеми митних органів, спеціалізованих митних установ та організацій, що взаємодіють з автоматизованою інформаційною системою «Центр»;

відомчу телекомунікаційну мережу митних органів, що забезпечує інформаційний обмін між елементами Єдиної автоматизованої інформаційної системи; локальні обчислювальні мережі митних органів, спеціалізованих митних установ та організацій;

інформаційно-телекомунікаційний комплекс митних органів «Електронна пошта», що забезпечує обмін електронними поштовими повідомленнями між користувачами ЄAIC ДМС Україн, забезпечує доступ до документа орієнтованих баз даних і складається 3 головного інформаційно-телекомунікаційного комплексу та регіональних інформаційно-телекомунікаційних комплексів;

адміністративно-правову інформаційну підсистему, що забезпечує управління митними органами на всіх рівнях, контроль і дотримання законності під час здійснення митної справи; підсистему інформаційного забезпечення, яка включає: комплекс технічного забезпечення; загальносистемне програмне забезпечення; нормативно-правове забезпечення; науково-методичне забезпечення; організаційне забезпечення системи; систему адміністрування та контролю функціонування програмно-технічних засобів; систему навчання та підвищення кваліфікації працівників (зокрема, і дистанційну форму навчання);

систему електронного документообігу ДМС України, що забезпечує автоматичне пересилання, реєстрацію та оброблення документів у митних органах, спеціалізованих митних установах та організаціях, контроль над ix виконанням, ведення електронного архіву документів;

комплексну систему захисту інформації, яка повинна забезпечувати захист державних інформаційних ресурсів в автоматизованих системах, що входять до складу ЄAIC митних органів, за допомогою впровадження комплексу технічних, програмних, криптографічних, організаційних та інших заходів i засобів комплексної системи захисту інформації, спрямованих на забезпечення конфіденційності, цілісності, доступності, керованості інформаціі;

підсистему криптографічного захисту інформації, яка повинна забезпечувати захищений обмін даними між інформаційними системами та автоматизованими робочими місцями структурних підрозділів ДМС України;

систему електронного цифрового підпису ДМС України, що становить автоматизовану систему, призначену для технологічного забезпечення надання послуг електронного цифрового підпису (далі - ЕЦП) в електронному документообігу користувачів EAIC митних органів [10].

Зазначимо, що практичне значення інформаційної системи важко переоцінити: «Це дає змогу володіти всією повнотою інформації про види контролю, які здійснювалися від першого перетину кордону до випуску у вільний 
обіг будь-якого товару. Дана система являє собою функціональний аналог таких передових європейських систем митного оформлення, як німецька «АТЛАС» та польська «ЦЕЛІНА», які $€$ взірцем та прикладом для наслідування під час розвитку будь-яких митних IT-систем», - зазначив заступник директора Департаменту інформаційних технологій ДМСУ Олександр Івашкович [11].

У процесі дослідження вважаємо за необхідне звернути увагу, що Концепція створення багатофункціональної комплексної системи «Електронна митниця» визначає, що важливими пріоритетами у використанні інформаційних технологій у сфері зовнішньоекономічної діяльності $€$ впровадження комплексної системи управління ризиками та розвитку системи електронного декларування.

Одним з основних модулів АСМО стала інтегрована в неї Автоматизована система аналізу та управління ризиками (АСАУР), яка дає змогу створювати профілі ризику довільної складності 3 використанням таких інноваційних підходів, як алгоритми нечіткої логіки (fuzzy logic) та врахування позитивної і негативної історії попередніх митних оформлень.

«Сьогодні АСАУР охоплює більше ста тисяч орієнтувань, регіональних та центральних профілів ризику. Інформація від суміжних держав дає змогу всебічно та повноцінно оцінити будь-які загрози, які можуть виникнути під час митного оформлення. У складі АСМО реалізовано систему обліку митних платежів, модулі митного оформлення громадян тощо», - підкреслив Олександр Івашкович [11].

Зазначимо також той факт, що у складі АCMO ефективно діє система електронного декларування вантажів: в електронному вигляді оформлюється вже понад 95\% митних декларацій [11].

Електронна форма декларування створює необхідні умови й орієнтована на реалізацію єдиного наскрізного алгоритму автоматичної обробки заяв- лених у декларації відомостей у Центральній базі даних на рівні управлінь митниць із здійсненням автоматичного аналізу ризиків та видачі відповідних рішень уповноваженій посадовій особі митного органу.

Таким чином, наріжним питанням залишається вдосконалення діяльності митних органів у напрямі автоматизації процесів митного оформлення і митного контролю шляхом консолідаціï зусиль на спрощення та створення сприятливих умов для всіх боків митного процесу, розвитку всіх складників е-митниці, запозичення найкращого світового досвіду впровадження IT у митну справу з урахуванням особливостей національної митної системи.

Під час реалізації завдань, що стоять перед ДМС України у царині створення інформаційного середовища, окрему увагу потрібно приділити питанню захисту і збереження інформації. Цей крок підвищить довіру до митних інституцій із боку бізнес-середовища.

У статті досліджено питання правового забезпечення діяльності митних органів України у царині автоматизаціі митного оформлення, зокрема під час здійснення митного декларування в електронному вигляді та кроків, що здійснюються в напрямі реалізації концепції «електронна митниця». Проаналізовано положення основних нормативно-правових актів, щз відіграють концептуальну роль у правовому регулюванні діяльності митних органів України з питань інформатизаціі.

Розглянуто профільні правові джерела, які нормативно закріплюють та деталізують перелік функиій окремих структурних підрозділів митних органів України.

Окремо зазначено виняткову важливість положень Міжнародної конвенціі про спрощення та гармонізацуію митних процедур (Кіотської конвенціі), яка займає особливе місие в розбудові інформаційного митного простору $i$ розглядае використання 
інформаційних технологій як один із фундаментальних принциипів митної справи.

Зазначено, що сьогодні нові підходи до діяльності митних органів на шляху інформатизації та створення електронної митниці $у$ цілому визначені, однак вони встановлені, як правило, на основі міжнародних стандартів та кониептуальних документів. Зазначено, що реалізація таких стандартів повинна проводитися за допомогою своєчасних коректив національного законодавства, що регулюе різні напрями діяльності митних органів. Тільки так можна досягти ефективних результатів у реформаторській діяльності в галузі митної справи.

Наголошено на важливості організациї інформаційно-правового забезпечення захисту інформації в митній справі, зокрема під час електронного декларування в процесі митного оформлення. Цей важливий аспект об'єктивно передбачає впровадження в правозастосовчу діяльність митних органів сучасних інформаційних технологій - методів інформатизації проиесів $i$ етапів управління, що, своєю чергою, виконує функцію забезпечення управлінської діяльності $i$ передусім проиесу генераціi управлінських рішень.

Ключові слова: правове забезпечення, митне оформлення, електронне декларування, митна справа, митниця.

Gurzhii T. Legal providing of electronic form of declaration is at custom registration

The article examines the issues of legal support of the customs authorities of Ukraine in the field of automation of customs clearance, in particular in the implementation of customs declaration in electronic form and the steps taken to implement the concept of "electronic customs". The provisions of the main normative legal acts that play a conceptual role in the legal regulation of the activities of the customs authorities of Ukraine on informatization are analyzed.

The profile legal sources which normatively fix and detail the list of functions of separate structural divisions of customs bodies of Ukraine are considered.

The exceptional importance of the provisions of the International Convention on the Simplification and Harmonization of Customs Procedures (Kyoto Convention), which occupies a special place in the development of the customs information space and considers the use of information technology as one of the fundamental principles of customs.

It is noted that currently new approaches to the activities of customs authorities on the path of informatization and creation of electronic customs in general have been identified, but they are established, as a rule, on the basis of international standards and conceptual documents. It is noted that the implementation of such standards should be carried out with the help of timely adjustments to national legislation governing various activities of customs authorities. Only in this way can effective results be achieved in reform activities in the field of customs.

The importance of the organization of information and legal support for the protection of information in customs, in particular in the electronic declaration in the process of customs clearance. This important aspect objectively involves the introduction of law enforcement activities of modern information technologies - methods of informatization of processes and stages of management, which in turn performs the function of ensuring management activities and, above all, the process of generating management decisions.

Key words: legal support, customs clearance, electronic declaration, customs. 


\section{Література}

1. Міжнародна конвениія про спрощення та гармонізацію митних процедур (Kiотська конвенція) / Рада митного співробітництвв; Конвенція, Положення, Правила [...] від 18.05.1973, Приеднання від 05.03.2011. URL : http://zakon3.rada.gov.ua/laws / show/995_643 (дата звернення: 25.03.2020).

2. Конституиія України від 28.06.1996. Відомості Верховної Ради України. 1996. № 30. Cm. 141 .

3. Митний кодекс України : Закон України від 13 березня 2012 р. № 4495-VI. URL : http://zakon2.rada.gov.ua/laws / show /4495-17/paran151\#n151 (dama звернення: 25.03.2020).

4. Про інформацію: Закон України від 02 жовтня 1992 р. № 2657-XII. URL : https: / / zakon.rada.gov.ua / laws / show/ 2657-12 (дата звернення: 25.03.2020).

5. Про електронні довіриі послуги : Закон України від 13 лютого 2020 р. № 2155-VIII. URL : https: / / zakon.rada.gov.ua/laws / show / 2155-19\#Tехt (дата звернення: 07.07.2020).

6. Про схвалення Концепиії створення багатофункціональної комплексної системи «Електронна митниия»: Розпоря- дження Кабінету Міністрів України від 17 вересня 2008 р. № 1236-p. Офіuійний вісник України. 2009. № 93.

7. Крижанівська А.О. Європейський досвід впровадження інформаційних технологій у здійснення митних процедур. Митна справа. 2015. № 1(97). С. 37.

8. Таіров A.I. Інформаційне забезпечення функціонування органів державної влади : автореф. дис. ... канд. політ. наук : 23.00.02/278. Kü̈, 2010. 20 c.

9. Про створення Єдиного державного реєстру підприємств та організацій Украіни : Постанова Кабінету Міністрів України від 22.01.1996 № 118. URL : http:// zakon2.rada.gov.ua/laws/show/118-96-n.

10. Про затвердження Положення про Едину автоматизовану інформаційну систему Держмитслужби України : Наказ ДМС України від 04.11.10 № 1341. URL : http: / / sfs.gov.ua/baneryi/mitne-oformlennya/ subektam-zed / elektronna-mitnitsya / 62603.html.

11. Пресслужба Державної фіскальної служби України. Державна фіскальна служба Украӥни : вебсайт. URL : http:// sfs.gov.ua/media-tsentr/novini/ 248998. html (дата звернення: 07.07.2020). 